\section{Banality and intersubjectivity in art}

Quote: CASTRO, Fábio Fonseca de; CASTRO, Marina Ramos Neves de. Banality and intersubjectivity in art. Porto Arte: Revista de Artes Visuais. Porto Alegre: PPGAV-UFRGS, v. 22, n. 36, p.1-7, jan.-jun. 2017. e-ISSN 2179-8001. DOI: http://dx.doi.org/10.22456/2179-8001.80115

Translated by Ana Carolina Azevedo and Bruno Declerque

Abstract: This article aims to reflect on the banality of art in its quotidianity. It attempts to question by what social dynamics the common, the banal and the quotidian can come to have artistic value. The answer we seek to build for the question, observes this sensation in its dynamics of sociation, that is, as a bond, as a structure of the collective and experiential character of social life. By understanding the phenomenon as a total social fact, we can say that it is engendered and simultaneously engenders the societal bond in an intersubjective procedure that produces the shared sense.

Keywords: Art. Banality. Quotidian. Sociation/sociality. Intersubjectivity.

\section{INTRODUCTION: THE IMPORTANCE OF THE BANALITY OF ART}

A long discussion on the banality of art is present, although often not explicitly, in the reflection on art and aesthetics. The debate is present in the works from Dewey (1997), Gombrich (1999), Huyghe (1998) and Maffesoli (1990). Other authors, such as Cauquelin (1998), Crispolti (2004) and Guyau (2009) also mention it on their reflections on the uses that contemporary society makes of art, beauty and taste. In general, the banalization of art appears as the opposite theme, par excellence, to the question of the essentialization of art as a value system by modern and contemporary societies. What these authors point out, in general, is the need to think of art, first of all, in its organic dimension, that is, inalienable to the doing, to the being, to the daily exchange of social life.

However, to organically think art does not answer the tangential problem of the social nature of the work of art, because it is evident to all these authors, though the question is not usually formulated, that the organic dimension is not the only present in what, by different approaches, can be called "taste", "beautiful", "art", "aesthetics", etc. Neither the complete imanentism nor the radical transcendentalism. It is not enough to understand the totality of art as a banal, quotidian and immersed in ordinary life fact; it is also necessary to question by what dynamics the common, the banal and the daily life can come to have value as taste - and here we try not to positivize the idea of taste, by understanding it as pleasure; on the contrary, we understand taste as sensation, that can be of pleasure or not.

The answer we seek to build for the question observes this sensation in its dynamics of sociation, that is, as a bond, as a structure of the collective and experiential character of taste. By understanding the phenomenon of taste as a total social fact - that is, in the Maussian concept, as a complex phenomenon which in itself has dimensions that are aesthetic, economic, political, etc. - we can say that it is engendered and engenders the societal and intersubjective bond which produces the shared sense. What produces the totality or the organicity of art? The fact that this totality or organicity is produced intersubjectively. So, in summary, our understanding.

We begin the article by observing how the question of the banality of art is present in Dewey, Gombrich and Huyghe. Then, through Maffesoli, we put in the perspetive the Simmelian approach of sociation, understanding it as the mechanism that allows us to think of art in its intersubjective dimension. We then conclude the article by organizing the elements that allow us to think art through the societal and intersubjective bond that produces the shared sense.

\section{THE THEME OF THE BANALITY OF ART IN DEWEY, GOMBRICH AND HUYGHE}

In speaking about the experience of art, Dewey notes that what we call art is present in the early stages of man's production as a social being. This production is presented through the creation and manufacture of objects and tools to satisfy daily needs such as those destined for domestic use, worshiping, production, reproduction, war, among others. It is important to note that these productions also present, throughout human history, a symbolic character that has been exhaustively explored by the history of art and societies. In making his analysis of art as an experience, Dewey points out how painting and sculpture were organically linked to architecture and the everyday life, being socially intended and produced, as one thing. 
In this social and collective experience there would be no differentiation in respect to an "artistic" perception of these tools and the ways of using them: there was a utilitarian purpose, but there was also an imponderable dimension, due to the interrelation between the individuals that, in our opinion, corresponds to what Simmel understands as sociation.

Similarly, music and song were intrinsically part of religious cults - even if they were not crossed by an artistic distinction while preserving a given purpose and intersubjective dimension. Dewey thus emphasizes, although not using the term, the intersubjective connection between art and the everyday life, pointing to the impossibility of thinking of one, without thinking of the other (DEWEY, 1980, p.8). When Dewey states, for example, that

The intelligent mechanic, committed to his work, interested in doing it well and who finds satisfaction in his manual labor, treating with genuine affection his materials and tools, is artistically committed. (DEWEY, 1980, p.8).

In the first place, we can see, in his thought, these two dimensions to which we refer to as - that of the use, the purpose of the mechanic's work, and that of the subjective satisfaction of the well-done work. This satisfaction, however, wouldn't be properly subjective, as it does not correspond to a symbolic production that is born and dies in the mind of the mechanic, but rather a socially and, therefore, intersubjectively shared value. Similarly, the dimension of use would necessarily be equally intersubjective, since the mechanic's work takes place in a context: its value is not enclosed and restricted to the interest of the mechanic, but rather to a dynamic of social self-production of its use, to which confers, also intersubjectively, value to this object or action.

Where, in this example, is the art, the "affection," the "artful commitment" that Dewey speaks of? Evidently in this intersubjective and socially shared relationship. That is why Dewey dissaproves the restricted understanding of art, which perceives it as the sublime production of a spirit, as something destined for contemplation and produced according to the mechanism of an individual subjectivity:

For when what it is known as art is relegated to the museum or to the gallery, the uncontrollable impulse towards experiences that can be enjoyed in themselves finds as many escapes as the environment provides (DEWEY, 1980, p.6).

We see, therefore, that the intersubjective character is one of the main elements of art, and that art can, as its function, be present in all human activities: both in the construction of everyday and mundane artifacts, such as a comb or a spoon, as in the construction or use of a building; both in the handcraft work as in the bureaucratic or mechanical work, and, also, in the fleeting and ordinary manifestations of human behavior in the face of a desire, of a belief, of an exchange, of an act of bonding - of a sociation, we could say, using Simmel.

Dewey emphasizes the functional character of artistic objects, listing them in their diversity:

The useful domestic tools of the house, like the shrouds, mats, jars, plates, bows, spears, were decorated with such care that we now pursue them and give them a place of honor in our museums. However, in their own time and place, such things were ways of exalting the processes of everyday life (DEWEY, 1989, p.7).

But we may also think that functionality is not an absolute value, although it may be present as it is present in social relations. This idea seems tangent to us in Dewey's thought when he relates intersubjective elements of social life that are centered on nonfunctional processes, such as the tools that,

Instead of placing themselves in separate niches, they belonged to the display of prowess, to the manifestation of solidarity of the group or clan, to the worship of the gods, to festivals and feasts, to fighting, to hunting and to all the rhythmic crises that scored the current of living (DEWEY, 1989, p.7).

Thus, when Dewey discusses the aesthetic dimension present in objects and their uses, in their quotidianity and banality, he is not reducing the aesthetic dimension to an exclusive functionality. On to the opposite, in doing so, he is actually noting that, even in its functionality, even in its banality and quotidianity, it is possible to achieve, in ordinary and mundane tools and uses, a dimension that concerns taste, beauty, non utilitarian pleasure and, possibly, also aesthetic. The aesthetic perception is a subjective component of this social experience which we understand as "taste", something that can be present in any activity, ordinary or not, that generates pleasure and displeasure in man, here understood as a collective, social being (Dewey, 2000, p.11).

The taste consists of the intersubjective action par excellence, and this intersubjectivity, evoked as experience, would consist of the presence of art, in an indistinct and banal manner, in the various human activities. It is this dimension that confers to not necessarily elaborated tools an artistic "purpose", a dimension empowered by the taste. The same dimension can be found not only in the elaboration of the object, but also in its use. For 
example, not only in the constructed housing, but also in its use; not just on the comb or the spoon, but also on how these two objects are used. And it would, still, be present in the manifestations of human behavior in society:

The collective life that manifested itself in war, in worship, or in the forum, did not know the division between what was characteristic of these places and operations, and the arts that brought them color, grace and dignity. (DEWEY, 1989, p.8).

This same idea about the banality and the quotidianity of art is present in Gombrich (1999), when, in the first chapter of his "The Story of Art", he observes that if we think of art as a form of human activity and manifestation, there is no civilization, there is no ethnicity in which the idea of art ceases to be present, usually in an untimely manner, devoid of canons and of conceptual closures that are generally present in Western civilization and in the closures operated by "history of art" and by "classic" aesthetic. Gombrich observes how the definition of the word art is ambiguous and diverse:

There is really nothing that can be called Art. [...] It does not harm anyone to call art all these activities, provided they keep in mind that such a word can mean very different things, at different times and places, and that Art with a capital A does not exist. (GOMBRICH, 1999, p.7)

Gombrich indicates, in short, that art is something negotiable, and that its definition is associated to a certain time and to a certain place. Art is generated by a certain experience, culture; its shape changes and passes through negotiations. What is art here and now may not be in another context. From this perspective, there would be no thing, in definitive way, we can call art. There would be no such thing as a universal, categorical and unquestionable concept in itself.

In this sense, Gombrich notes that the objects and images produced by the first peoples or even by classical civilizations, for example, which are part of the so-called "history of art", were not necessarily created with the aim of provoking fruition. Its original production served specific purposes, usually utilitarian, quotidian and banalized, fulfilling functions of worship, protection or use in ordinary life. In this, we can refer to objects such as the Venus of Willendorf, the cave paintings of Lascaux, the sculptures of Greek athletes, Egyptian pyramids, sculptures and paintings, and tools of all kinds such as medieval combs and reliquaries, Indian masks, etc. The examples are too vast to be listed here, but Gombrich's conclusion clarifies the process: "[...] what we call 'work of art' is not the result of a mysterious activity but an object made by human beings for human beings" (GOMBRICH, 1999 , p.32). That is, art was born with human activity, organically linked to it in its daily life, shared in society.

Huyghe, starting from an art conception close to that of Gombrich,

[...] art is an essential function of man, indispensable to the individual and to societies, and that is imposed upon them as a necessity from prehistoric origins. Art and man are inseparable. There is no art without man, but perhaps there is also no man without art. (HUYGHE, 1998, p.11)

Despite the use of the word "man", the association between "man" and "humanism" must be avoided in the understanding of Huygue's work, in the traditional - and metaphysical - sense of spiritual humanity; that is, the understanding that art is produced as a refinement of sensibility and value judgment. In this author, an understanding of art as a social and collective experience is tangent:

Thus art is in solidarity with man. With so much diversity and flexibility with the customs, it changes with the centuries and the latitudes. (HUYGHE, 1998, p.13).

Huyghe emphasizes that art should be thought of as an essential function of social life. A creature that lives in society and that in it makes its exchanges, shares its and other worlds, creates and re-creates incessantly, man has in art an instrument, a necessary subjective tool for the production of his reality and his being in the world.

We can conclude that, through art, man forms and conforms an important stage of his social bond, of his association with other individuals or, more specifically, his sociality.

The concept of sociality that we use comes from Maffesoli, which, in turn, has its source in Simmel. In Simmel, the interaction between individuals, their reciprocal provision, constitutes the "Vergesellschaftung", a term that can be translated into English as sociation, the process through which people produce empathic bonds. For Simmel, a society thought as a sociation between individuals, as a figure with its own totality, does not exist; what exists, in fact, would be this process of sociation, or of construction of the societal bond, between individuals. According to Vandenberghe (2005, p.77), for Simmel, "society is not a concrete substance but a process of association, that is, a process that is continuous 
and creator of spiritual interactions between individuals, rebonding them to one another". It is such a collective form of interaction that leads Maffesoli (2000), Simmel's interpreter, to elaborate his reflection on feeling together, qualifying it as a form of sociation, or more specifically, as the process of identification produced as impetus of attraction, aggregation, belonging, sharing, socialization, bonding, alliance, attachment to the collective body. In this sense, it can be said that it is precisely this feeling together that conforms the binding to which Simmel refers, that connects the elements that conform the social body.

But let us go back to Huygue to remember that he affirms that art and man are inseparable, and that there isn't one without the other. We can observe, preserving the understanding of man not as the individual and sensitive being idealized by humanism, but as a natural and collective being, that, in this way, the concept of art also in Huygue corresponds to an idea of intersubjectivity and, therefore, to the process of sociality. It is in this sense that Huygue emphasizes that art is in solidarity with man, because it is inherent to him, to the point of accompanying him in his experience and sharing of the world - and in this accompaniment, it shares the diversity and flexibility in relation to culture - it changes, following man in his sociality, in the course of his being in the world and thus transforming himself, according to his social experience of temporality and spatiality.

\section{ART AND SOCIATION IN MAFFESOLI}

The three authors, Dewey, Gombrich and Huygue, depart from the peculiarities of the collective, intersubjective, cultural and social man, as well as from the needs of the collectivity to establish a reference for what we can understand as art. For them it is undeniable that, since the most archaic times, art has never been separated from other social activities. It was never thought of separately or fragmented in relation to socially developed activities, because it was intrinsically linked to the daily life, which allows us to conclude that there is no social experience without art, and that there is no art without social experience. Art is closely linked to the human being, to his way of being in the world and, therefore, to the development of his sociations. Art is where man is, in his sociality.
And, therefore, in his collective and intersubjective experience, what brings us back to Maffesoli and his perception of being together, of sharing, of feeling in common that this thinker understands as being the fundamental ethos of all collectivity (Maffesoli: 1990; 2000). Indeed, Maffesoli continues along the same path as Dewey, Gombrich, and Huygue in relation to the understanding that beauty, taste, and aesthetics are an intersubjective and naturalized experience of social life. However, as expected from a Simmelian sociologist, he displaces the sense of the taste from a social field understood as lived experience, or, as the content produced by those experiences, to a field centered on the bond, on the ongoing experience, on the experience as a bonding process or, more precisely, as a sociation, the interpersonal and collective relationships and benefits.

We can see the Simmelian heritage in Maffesoli in the understanding of this author that social life has as its fundamental phenomenon the continuous production of the link between individuals through an intersubjectivity produced by forms rather than by content.

In our judgment, Maffesoli completes the thought of the three authors covered earlier through his discussion on the feeling together, the intersubjective faculty of consubstantiating in social experience, the banal and quotidian character of the work of art and allows us the possibility of going a little further with its formist perception in the sense of perceiving that the organic character present in the thought of the three authors mentioned above, also, corresponds to a process of sociation.

To better understand this situation, let us briefly look at Maffesoli's thought on aesthetics. First, it should be noted that the idea of aesthetics in it is not limited to the contemplative character - be it art, or life. His interest concerns what we may call the active character of perception, as part of ordinary activities that bring forms-of-being-together, in which states of enjoyment, perception, and interaction with the world occur. For him, the aesthetic is not necessarily linked to happiness and pleasure, but to any collective process given by interaction. It is in the collective action of individuals, in their interaction, in the alteration of their being-in-the-world, that the individual becomes an active and passive agent, concomitantly, of the world he experiences: 
[...] aesthetics is not individualistic, but rather, constitutes a global mass where, in an organic way, all the material and spiritual elements of the social and natural body enter into perpetual synergy (MAFFESOLI, 1990, p.278) ${ }^{1}$

Maffesoli thinks art as something organic and daily produced by man in his relation to the other, that is, in the association, in the interaction, in a dynamic of the constitution of bonds that ends up producing communions of perception and multiplying the bonds between the individuals and the elements of the ordinary life, even when these are contrary or contradictory, provided that they conform to a form of being together.

Maffesoli understands art through the extension of the German concept of Kunstwollen, this artistic will, this manifestation of the spirit of a time that results from the common feeling of social life (1990, p.22). This concept, debated by the art historian Alois Riegl , points to this artistic will conditioned by the world perspective proper to a community, to a sociality, in his experience of production of meaning on his own common experience.

This artistic will, these concrete manifestations of the spirit would be present, according to Rieg| ${ }^{2}$ (2012) in all forms of being together, in all associations, since, when a social relation is produced, what is produced, as a result, is fundamentally an exchange, a sharing, before even taking into account the judgments of values that are made in connection with this sharing, that is, of the contents also produced. These sharings - sociations, in the Simmelian sense - are consequences and results of the collective emotions produced in the social bond.

The inventory of possible examples is endless: it embraces everything that is emotionally activated collectively, regardless of physical or temporal dimensions, whether in a football crowd, in a music show or in the face of a dramatic everyday event that catalyzes attention, for example. But it would also occur in a temporarily prolonged experience, even if for several generations of common taste or values - that which is good or beautiful, or bad and ugly at a fair, for example; or in a shared worship experience over the long duration

1. "[...] l'esthétique n'est rien moins qu'individualisée, mais constitue plutôt une masse globale où, d'une manière organique, tous les éléments matériels et spirituels du corps social et naturel entrent en une perpétuelle synergie.". (MADDESOLI, 1990, p.278). Author's translation.

2. Frank, Isabelle. Alois Riegl (1858-1905) et l'analyse du style des arts plastiques. In: Littérature, Number 105, 1997. p.66-77. of a community. In all of these collectives that, eventually, become interrelated, there will be an experience of emotional sharing, a sociation that has an aesthetic dimension.

Thinking with Maffesoli in mind, it would no longer be possible to understand art exclusively in the works institutionalized by the art system - that system which Coquelin discusses, observing it as a network of mediators, between the artist, his work and the public, contribute to the legitimation, as art, of certain objects and practices (Coquelin, 2005, p.65-84). It would be necessary to include in this vision also the organic, banal and quotidian whole that, in everyday life, in everyday situations and practices, no matter how small, make up what, from the thought of Simmel, Maffesoli calls association or sociality: the social life in its production, including its banal objects and processes, for the same "constituent le terreau sur lequel s'élèvent culture et civilisation." (MAFFESOLI, 1990, p.22)3. Thinking similarly to Dewey, Maffesoli states that

The art that will be observed in the overcoming of the architectural functionalism or that usual object. From a type of life to a domestic ad, everything is meant to become a work of creation, everything can be understood as the expression of a first aesthetic experience. Therefore, art could not be reduced only to artistic production, I mean those of artists, but becomes an existential fact (MAFFESOLI, 1990, p.12) ${ }^{4}$

Maffesoli, like Dewey, Gombrich and Huygues, contributes, according to our understanding, to the understanding of art as an intersubjective fact, as something that has existence independent of the negotiations between the social actors that belong to a closed field, said artistic, that conforms in respect to the subject and the system of codes, values and references that he calls "art". With this proposition, Mafessoli allows us to reach a critical dimension that, although tangential to the works of Dewey, Gombrich and Huygues, is not yet formulated: the criticism to the modern

3. Let us make it clear that sociation is different from socialization; sociation enacts social processes, a notion analogous to the social form, a notion that is also present in Simmel and Maffesoli. The sociation takes place in the collective social experience marked by the emotional bond, by vitalism, by internal reason, by organic thought, and finally by a feeling together where the affinities and differences inherent in human relations are present. "[...] toutes ces choses anodines qui, par sédimentation, constituent la trame de la socialité banale." (MAFFESOLI, 1990, p.20).

4. "L'art qui va s'observer dans le dépassement du fonctionnalisme architectural ou dans celui de l'objet usuel. Un cadre de vie à la réclame du design ménager, tout entend devenir oeuvre de création, tout peut se comprendre comme l'expression d'une expérience esthétique prémière. Dès lors, l'art ne saurait être réduit à la seule prodution artistique, j'entends celle des artistes, mais devient un fait existentiel." (MAFFESOLI, 1990, p.12). Author's translation. 
episteme, through the realization that it rests, essentially, on a separation between nature and culture, intangible to the contemporary - or non-modern, or even postmodern look, which allows one to understand the present organicity, precisely between these two spheres, in its elements

[...] of totally disparate elements that establish constant interactions between one another made of aggressiveness or kindness, love and hate, but which constitute a specific solidarity that must be taken into account.(MAFFESOLI, 1990, p.15) ${ }^{5}$.

The idea of intersubjectivity becomes, in Maffesoli, the idea of "culture of feelings" (MAFFESOLI, 1990, p.31), that is, the perception that emotions, fruit of the attractions aroused by desires and feelings of belonging produced in the sociation of individuals, occur simultaneously as an aesthetic and ethical link:

[...] the value, the admiration, the hobby, the taste that is shared become cement, they are vectors of ethics. To be more precise, I call ethics a morality "without obligation or penalty"; without obligation other than that of adding, of being a member of a collective body, without penalty other than that of being excluded, ending the interest that binds me to the group.(MAFFESOLI, 1990$, p.31 $)^{6}$

Aesthetics constitutes a feeling of ethics in relation to the collective and, thus, a feeling together capable of generating social forms. It is the same conception of art as that of Gombrich, Huygue, and Dewey: art as an organic production of meanings - with the addition of the formulation on the sociation as a engine to the aesthetic process and of the critical formulation to the process of subjection, of the aesthetic process itself, certain values about what the beautiful is.

\section{ART AS AN INTERSUBJECTIVE PHENOMENON}

We can conclude that art is something that, naturally, is produced by man in his processes of being together and feeling together, in his process of being in the world and participating in this world, which is, mainly, done through an

5. "[...] totalement disparates que établissent entre eux des interactions constantes faites d'agressivité ou d'amabilité, d'amour ou de haine, mais qui n'en constituent pas moins une solidarité spécifique qu'il faut prendre en compte.". (MAFFESOLI, 1990, p.15). Author's translation.

6. "[...] la valeur, l'admiration, le "hobby", le goût qui sont partagés deviennent ciment, sont vecteurs d'éthique. Pour être plus précis, j'appelle éthique une moralle "sans obligation ni sanction"; sans obligation autre que celle de s'agréger, d'être membre du corps collectif, sans sanction autre que celle d'être exclu si cesse l'intérrêt (inter-esse) qui me lie au groupe." (MAFFESOLI, 1990, p.31). Author's translation. ordinary and collective knowledge which, experienced in daily life of interactions, experienced intersubjectively, dispenses all aurification, all differentiation and all protection conferred by the title of "art", or "work of art."

Art is generated in the process of sociation, in sociality, and ontologically, exists only there. That is, it is provoked, generated, cultivated and sustained in the experience, in the experience of being together. Hence, it is intersubjective, it is intrinsically related to the activity and social experience. Art conforms, according to sociality, with the way that men have of establishing interactions; it is one of the results of a way of being together. It is form, since it is conformed by a process of interactivity and its occurrence is only possible in society, or rather, in the process of sociation.

On this perspective, we can put the question stated at the beginning of this article: to what extent, exactly, is art banal? To what extent, can we say that it is banal?

The first response derives from the fact that art, or the feeling of taste, is a total social fact. The concept of Mauss (2003) thus understands social phenomena characterized by a complexity that would not be possible to be understood, exclusively, through a single dimension, be it economic, political, religious, linguistic, cultural, aesthetic, etc. .

Being a total social fact, the taste or the art conform a process of composite overlapping of social relations, a process that is equally complex, that is, characterized by the impossibility of being reduced to vectors of interest and power or to objective forms of understanding the social bond.

In order to better understand this process, we find in Simmel's work a development of the perception of this type of complexity through the Wechselwirkung notion, which could be translated to reciprocal effects or effects of reciprocity, the general phenomenon that leads to the production of sociations, or a process of empathic construction of social bonds. Papilloud (2002) discusses at length the relationship between Mauss and Simmel's thoughts, understanding that, even though they occupy different epistemological positions, there is a close proximity and even a methodological complementarity between them (PAPILLAUD, 2002, p.31).

Maffesoli's approach to taste and art is directly a tribute to Simmel's thought. His perception that the aesthetic is produced 
as ethos comes from the Simmelian reading that what forms the society are those effects of reciprocity that are at the base of human life and that conform the whole social experience.

If we understand this process as an intersubjective social dynamic, it is based on the idea that the reciprocity effects constitute not simply an event of commutation of subjectivities, a communion of subjects, but simply the fundamental phenomenon that makes society work. It is necessary to clarify that our perception on the phenomenon of intersubjectivity starts from the Heideggerian critique (1993) to Husserl's thought that intersubjectivity would be the commutation between subjectivities, the communion between subjects. More than that, Heidegger suggests, intersubjectivity constitutes the very ontological procedure - and, therefore, characteristic of the human being - that gives meaning to living together, to the social being.

If art is banal - or rather, if there is a banality in taste - it is because, therefore, it commutes intersubjectively.

\section{REFERENCES}

ARGAN, G.C.;FAGIOLO, Maurizio. Guia de História da Arte. Lisboa, Ed. Estampa, $2^{\mathrm{a}}$ ed, 1994

BOURRIAUD, Nicolas. Estética Relacional. São Paulo: Ed. Martins Fontes, 2009.

CAUQUELIN, Anne. Les Théories de l'art. Paris, PUF, 1998 . Arte Contemporânea: uma introdução. São Paulo: Martins Fontes. 2005

CRISPOLTI, Enrico. Como Estudar a arte contemporânea. Lisboa: Editorial Estampa, 2004

DEWEY, John. El arte como experiencia. Barcelona, Ed. Paidos Estética 45, 2008

DURAND, Gilbert. As Estruturas antropológicas do imaginário. São Paulo: Martins Fontes, 1997

FRANK, Isabelle. Alois Riegl (1858-1905) et l'analyse du style des arts plastiques. In: Littérature, $\mathrm{N}^{\circ} 105,1997$.

GADAMER, Hans-Georg. Hermenêutica em retrospectiva. Vol II, Petrópolis, Vozes. 2007

GOMBRICH, Ernst. A História da Arte. Rio de Janeiro: LTC; $16^{\mathrm{a}}$ edição, 1999

GUYAU, J.M. A arte do ponto de vista sociológico. São Paulo, Martins Fontes, 2009

HEIDEGGER, Martin. Ser e Tempo, 2 vols, 4a ed. Petrópolis: Vozes, 1993.

HUYGUE, René. O poder da imagem. Lisboa: Edições 70, 1998
JOLY, Martine. Introdução à análise da imagem. Campinas: Papirus, 1996

MAFFESOLI, Michel. O Paradigma Estético, in SOUZA, Jessé e ÖELZE, Berthold, Simmel e a Modernidade. Brasília: Editora da UnB, 2005 . Revista Informação / PUCRS - Março/Abril de 2010. . Au creaux des apparences. Paris : PLON., 1990 Le temps de tribus. Paris : Ed. La table ronde, 2000.

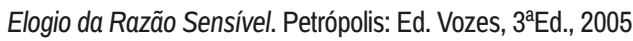

MAUSS, Marcel. Sociologia e antropologia. São Paulo: Cosac \& Naify, 2003

PAPILLAUD, Christian. Le don de relation. Georg Simmel - Marcel Mauss. Paris, l'Harmattan, 2002.

RICOEUR, Paul. Tempo e narrativa, vol. I. São Paulo, Papirus, 2000. Hermenêutica e ideologias. Petrópolis, Vozes, 2008. Do texto à ação. Ensaios de hermenêutica, vol. II. Porto, Rés, 1989.

SIMMEL, Georg. "Sociabilidade: um exemplo de sociologia pura ou formal". Georg Simmel: sociologia. São Paulo, Ática, org. [da coletânea] Evaristo de Morais Filho, 1983

VANDENBERGHE, Frédéric. As Sociologias de Simmel. Bauru: EDUSC; Belém: Ed. Universitária UFPA, 2005.

WAIZBORT, Leopoldo. As aventuras de Georg Simmel. São Paulo: Edições 34, 2000.

Fábio Fonseca de Castro: Professor of the Postgraduate Programs in Comunicação, Culture and Amazon and in Sustainable Development of the Humid Tropics, UFPA. PhD in Sociology by the University of Paris V Post-doctorate by the University of Montréal.

Marina Ramos Neves de Castro: Doctoral student in Anthropology at PPGA-UFPA. Master in Arts by PPGArtes-UFPA. Master in Latin American Societies Studies by IHEAL-Sorbonne Nouvelle

$\left.{ }^{*}\right)$ This text was submitted in october, 2014 and updated in 2017 for this publication. 